University of Wollongong

Research Online

Faculty of Business - Papers (Archive)

Faculty of Business and Law

2013

Does bank ownership imply efficient monitoring? Evidence from bank lending and firm investment efficiencies in China

Gary G. Tian

University of Wollongong, gtian@uow.edu.au

Xiaofei Pan

University of Wollongong, xpan@uow.edu.au

Follow this and additional works at: https://ro.uow.edu.au/buspapers

Part of the Business Commons

Research Online is the open access institutional repository for the University of Wollongong. For further information contact the UOW Library: research-pubs@uow.edu.au 


\title{
Does bank ownership imply efficient monitoring? Evidence from bank lending and firm investment efficiencies in China
}

\author{
Abstract \\ This study investigates the effect of bank ownership on lending and firm investment efficiencies to give \\ reasons for the mixed evidence that exists on the impact of bank ownership on firm performance. Using \\ China's listed firms as an example, we find that bank ownership reduces the efficiency of bank lending \\ and harms investment efficiency for state-owned enterprises (SOEs), while simultaneously relating to \\ optimal lending decisions and enhanced investment efficiency for non-SOEs. Our findings suggest that \\ banks monitor non-SOEs effectively, but are less effective at monitoring SOEs. We document that banks' \\ ex post monitoring on non-SOEs' investment policy results from their more effective ex ante monitoring of \\ their lending decisions. Further analysis suggests that bank ownership hurts firm performance for SOEs \\ while enhancing firm performance for non-SOEs. Overall, we document that in an emerging market where \\ SOEs and non-SOEs co-exist, bank ownership affects firm performance by influencing the lending \\ decision and firm investment policy, while the effectiveness of their monitoring varies with the firm's \\ ownership structure.
}

\section{Keywords}

investment, firm, china, efficient, does, imply, monitoring, ownership, bank, efficiencies, evidence, lending

\section{Disciplines \\ Business}

\section{Publication Details}

Tian, G. G. \& Pan, X. (2013). Does bank ownership imply efficient monitoring? Evidence from bank lending and firm investment efficiencies in China. Australasian Finance and Banking Conference (pp. 1-29).

Australian School of Business, University of New South Wales. 


\title{
Does bank ownership imply efficient monitoring? Evidence from bank lending and firm investment efficiencies in China
}

\author{
Xiaofei Pan, School of Accounting and Finance, University of Wollongong \\ Gary Tian*, School of Accounting and Finance, University of Wollongong
}

\begin{abstract}
This study investigates the effect of bank ownership on lending and firm investment efficiencies to give reasons for the mixed evidence that exists on the impact of bank ownership on firm performance. Using China's listed firms as an example, we find that bank ownership reduces the efficiency of bank lending and harms investment efficiency for stateowned enterprises (SOEs), while simultaneously relating to optimal lending decisions and enhanced investment efficiency for non-SOEs. Our findings suggest that banks monitor nonSOEs effectively, but are less effective at monitoring SOEs. We document that banks' ex post monitoring on non-SOEs' investment policy results from their more effective ex ante monitoring of their lending decisions. Further analysis suggests that bank ownership hurts firm performance for SOEs while enhancing firm performance for non-SOEs. Overall, we document that in an emerging market where SOEs and non-SOEs co-exist, bank ownership affects firm performance by influencing the lending decision and firm investment policy, while the effectiveness of their monitoring varies with the firm's ownership structure.
\end{abstract}

Key words: Bank ownership, Lending efficiency, Investment efficiency, SOEs and nonSOEs, Conflict of interests, China

JEL: G31, G34, G21

\footnotetext{
* Gary Tian is corresponding author, his email is gtian@uow.edu.au. Xiaofei Pan’s email address is xpan@uow.edu.au.
} 


\section{Introduction}

A large body of literature argues that banks are able to provide more efficient debtrelated external monitoring for the corporate governance of firms because they have a comparative cost advantage in accessing superior inside information (Fama, 1985; Datta et al., 1999). However, if banks hold the equity of companies, they also have incentives to also exert internal monitoring. Recently, an evolving literature began to focus on bank holding ownership of non-financial companies and its consequence on the corporate governance system. These studies tend towards views regarding the effect of bank holding ownership (we use bank ownership later in the paper) on firm performance with no agreement. One view agrees that banks can obtain proprietary information of companies by holding their equities and evidence from developed markets supports the notion that bank ownership is beneficial to companies. These studies argue that bank ownership can promote companies' access to bank capital and exercise effective monitoring, which can improve firm performance (Kang et al., 2000; Kroszner and Strahan, 2001; Bris et al., 2006; Mahrt-Smith, 2006). The other view focusses on bank's harmful effect and argues that being shareholder and lender, bank ownership leads to more serious potential conflict of interests in emerging markets where the bank is the main capital provider and bank credit is scarce and highly regulated by the government (Cull and $\mathrm{Xu}, 2000$ ). There is evidence to suggest that although bank ownership allows companies to have better access to debt financing in emerging markets, banks also monitor less, and bank ownership does not necessarily improve firm performance (Fok et al., 2004; Limpahayom and Polwitoon, 2004; Lin et al., 2009).

Although the effect of bank ownership on firm performance has been established with mixed results, there is no comprehensive analysis showing the mechanism through which bank ownership works to affect firm performance in an emerging market. Moreover, although previous studies conjecture that banks may extensively monitor their loans through their ownership of the borrowing firms, these studies provide no direct evidence about how banks monitor firms and what are the related costs and benefits of bank ownership practice. In this paper, we attempt to address the following two questions: How does bank ownership influence bank lending decisions and firms' investment decisions? And what is the financial consequence of such bank ownership?

To answer these questions, we take on the perspective of banks' ex ante and ex post monitoring over their funds lending to achieve a better understanding of their monitoring role over corporate governance in emerging markets. In particular, we explore the channel(s) through which bank ownership affects firm performance by investigating how banks exercise 
ex ante monitoring through influencing lending decisions and ex post monitoring by influencing firm investment policies, using a sample of China's listed firms. We focus on both the lending decision and firm investment policy for the following reasons. First, existing studies document that bank ownership may affect banks' lending decision by providing evidence that bank ownership facilitates capital flow and promotes companies' access to bank capital (Kang and Shivdasani, 1995; Lin et al., 2009). In addition, bank lending can have an important influence on firms' investment policies (Lang et al., 1996; Kang et al., 2000; Aivazian et al., 2005; Firth et al., 2008). Second, the conflict of interest between shareholders and lenders creates incentives to deviate from optimal investment (Kang et al., 2000), and this interest conflict could be mitigated by permitting banks to hold equity in companies (Kroszner and Strahan, 2001). Moreover, existing literature finds that investment significantly influences firm performance because firm performance responds positively to better investment and gains from investments enhance firm profitability (Fama and French, 1998; Core et al., 1999; Hutchinson and Gul, 2004; Aggarwal and Samwick, 2006; Chen et al., 2009). Third, since the recent global financial crisis, bank lending and firm investment policy has attracted considerable interest from academics and practitioners. In response to the financial crisis, the Chinese government initiated an economic stimulus package to encourage bank lending and firm investment. Therefore, the economic stimulus package as an exogenous shock provided a unique opportunity for examining the effect that bank ownership has on lending decision and firm investment efficiency, with a reduced concern for endogeneity.

While banks holding equity of non-financial companies is not unique in China, the Chinese corporate and financial environment is particularly interesting for this research. First, China is the largest transition economy and is characterized as having an absence of mature public bond markets. Corporate external finance relies mostly on bank borrowing, so banks play a very important role in determining the availability of credit. In addition, the Chinese financial system is dominated by the government through the direct and indirect state ownership and control of most banks, while the lending decisions of these banks often reflects the policies dictated by government (Firth et al., 2009; Chen et al., 2013). This is to say that state-owned banks dominate Chinese financial system and they tend to allocate and price loans according to the preferences of the government.

Second, the co-existence of state-owned enterprises (SOEs) and non-SOEs in China provides another unique institutional environment to examine different effects of bank ownership on lending and investment efficiencies, and firm performance. Because the 
objectives of state-owned banks are to maximize their multiple objectives combined with political and economic ones, they tend to lend largely to SOEs and bail out poorly performing SOEs, and are able to ignore SOEs' non-performing loans (Cull and $\mathrm{Xu}$, 2003; Firth et al., 2008). Because the central government must bear the final responsibility for these consequences, state-owned banks have a lack of due-diligence monitoring over their lending decisions, and less incentives to exert disciplinary pressures on SOEs for their liabilities. If banks also become owners of SOEs, which indicates a better and more stable bank-firm relationship, these SOEs are more favoured by state-owned banks' lending which may eventually lead to an inefficient allocation of capital because these SOEs are more likely to get bank loans regardless of their profitability and creditworthiness (Zheng and Zhu, 2013). This soft lending then encourages SOEs with bank ownership to invest more into building their empires regardless of whether they have good investment opportunities or not. Therefore, this favoured lending to SOEs with bank ownership will reduce investment efficiency of these firms (Firth et al., 2008; Lin et al., 2009). In contrast, non-SOEs are similar to their counterparties in developed market and they have a simpler objective of value maximization (Chen et al., 2011), and banks are able to extend their discipline and monitoring to the non-SOEs firms they lend to (Santos and Rumble, 2006). Moreover, bank shareholders are eager to maximize their proceeds by advocating effective monitoring on firms' investments. On this basis the homogeneity of state ownership makes China an excellent context to examine the monitoring effect of bank ownership on bank lending decisions and firm investment policy across SOEs and non-SOEs. In addition, an investigation into the bank-firm relationship through bank ownership and empirical evidence on the effect of bank ownership on lending and firm investment efficiencies in an environment where state ownership dominates the financial system provides a useful addition to the literature.

Furthermore, the unique Chinese institutional setting for bank equity investments also allows us to further reduce any concerns of an endogeneity issue. Although the new Commercial Bank Law implemented in 1995 did not force banks to relinquish their existing ownership in listed non-financial firms, they have not been allowed to invest any new equity in non-financial firms since then. Therefore bank ownership during our sample period (2003 to 2010) is largely exogenously determined and less likely to be affected by the firm characteristics and corporate governance variables. This is perhaps the most significant advantage of using Chinese data in that it allows us to infer bank ownership whose formation predates, by several years, the lending and firm investment policy we wish to analyse. We 
argue that such a lag between bank ownership formation and lending and investment policy removes the reverse causality concerns to some extent. Nevertheless, we will also apply alternative approaches to dealing with the endogeneity issue, including a natural experiment, and a two-stage least square and fixed effect regression.

From the empirical analysis, we find that bank ownership reinforces the exercise of using commercial judgements in allocating capital to non-SOEs, which is consistent with previous studies (Firth et al., 2009; Chen et al., 2013), whilst bank ownership is more likely to reduce bank lending efficiency and lead to capital misallocation for SOEs. We further find that bank ownership is likely to enhance investment efficiency only in non-SOEs, while in SOEs bank ownership relates to a less efficient investment. Overall, our findings of the effect of bank ownership on firm behaviour suggests that inefficient firm investment is accompanied with inefficient bank lending decisions, and the effectiveness of banks' monitoring is reflected by both ex ante and ex post of their capital allocation.

Our findings also suggest that bank ownership in non-SOEs aligns the interests between lenders and shareholders by exerting effective monitoring function to enhance investment efficiency, while bank ownership in SOEs actually exaggerates the conflict of interests between lender and shareholder which results in less efficient investment. We argue that whether a bank plays a monitoring role by directly holding the ownership of companies relies heavily on the governance framework and ownership structure.

Our findings also confirm that bank ownership is less likely to add firm value for SOEs, which is consistent with the evidence from other emerging markets (Fok et al., 2004; Limpahayom and Polwitoon, 2004; Lin et al., 2009), while bank ownership is more likely to increase firm value for non-SOEs, which is similar to the case of developed markets. Our investigation complements the notion that bank ownership can be a double-edged sword in emerging markets.

This study contributes to the existing literature in the following ways. First, although the relationship between banks and firms through bank ownership, and its consequence on firm performance and valuation has recently evolved with mixed evidence, little is known about how bank ownership works to affect firm performance, especially in emerging markets. Specifically, the evidence from developed markets supports a positive effect of bank ownership on firm performance (Kang et al., 2000; Kroszner and Strahan, 2001; Bris et al., 2006), while evidence from emerging markets agrees with a negative effect (Fok et al., 2004; Limpahayom and Polwitoon, 2004; Lin et al., 2009). We propose that bank lending and firm investment are the channels through which bank ownership can affect firm performance. In 
particular, we argue that whether bank ownership can increase firm value depends heavily on the investment efficiency. Moreover, according to the existing argument that how banks monitor the borrower depends on the severity of the agency problems (Harvey et al., 2004), our evidence also adds new insight into optimal investment design resulting from mitigating the conflicts of interest.

Second, we complement a growing literature relating to the bank-firm relationship. Extant literature has suggested a few proxies for this relationship, such as relationship banking (Boot, 2000; Bharath et al., 2011), pre-existing borrower-lender personal relationship (Engelberg et al., 2012), holding bank ownership (Berger et al., 2009) and appointing bankers onto the board (Krosnzer and Strahan, 2001; Byrd and Mizruchi, 2005), while this study extends our understanding of bank's impact on firms' corporate decisions from a more direct perspective, namely bank holding ownership of listed companies. We argue that through their ownership holding, banks are able to vote on important corporate matters which will affect firms' financing and investment decisions. We also add additional evidence to the literature of bank-firm relationship in an emerging market. Extending from the evidence from developed markets (Gorton and Schmid, 2000; Kang et al., 2000; Kroszner and Strahan, 2001), and along with findings from other emerging markets (Fok et al., 2004; Limpahayom and Polwitoon, 2004; Lin et al., 2009; Luo et al., 2011), we conclude that how bank ownership works to affect corporate decisions relies on firm's ownership structure and the institutional and governance environment.

Third, we contribute to the literature of government intervention. The objective of the economic stimulus package initiated by the government is to drive back the GDP growth rate by bank lending and investing in the domestic market, so it is of a particular interest to understand the effect of the stimulus package on both bank lending and firm investment efficiency at the cross-sectional level. There are public concerns that the mounting bad debts and over capacities induced by the Chinese stimulus package could result in an economic crisis in China, which might be even worse than that in U.S. We will provide direct evidence for the impact of the economic stimulus package on economic efficiency by investigating whether both bank lending and investment efficiencies in firms with or without bank ownership has moderated or been exacerbated by this government intervention. More precisely, we attempt to disentangle the change in investment policies in these firms before and after the stimulus package implementation. In addition, the economic stimulus package can also be used as a natural experiment to alleviate any potential endogeneity concerns, because the economic stimulus package provided an exogenous policy shock to each 
individual firm where bank ownership was exogenously set outside the equation rather than being determined by a firm.

Fourth, we add new evidence to demonstrate the relationship between bank lending decisions and firm investment policies in the particular context of China. Extant studies focus on either how banks make lending decisions or how firms make investment policies. One strand finds that state owned banks tend to lend to SOEs regardless of their creditworthiness (Cull and $\mathrm{Xu}, 2003$ ), while they exercise commercial judgement in allocating capital to nonSOEs (Firth et al., 2009; Chen et al., 2013). The other strand finds that firm investment depends on investment opportunities and leverage level, while investment efficiency is largely influenced by government intervention (Firth et al., 2008; Chen et al., 2011; Zheng and Zhu, 2013). Our study aims to connect bank lending decisions to firms' investment policies and we provide new evidence to the literature that lower (better) investment efficiency has resulted from lower (better) lending efficiency, which was determined by bank monitoring and ownership structure.

Finally, our research adds new evidence to the literature concerning the effect of bank ownership outside of U.S. Because the existing regulations have prevented banks from investing equity in non-financial firms in the U.S., the literature on bank ownership is almost entirely related to Germany and Japan where banks' equity investments, which are allowed by their regulations, are a common phenomenon. Recently, an evolving literature relating to the bank ownership began to focus on emerging markets such as China (Lin et al., 2009; Luo et al., 2011), and of course our study enriches this literature by providing additional evidence of the effect of bank ownership on bank lending decisions and firm investment policies.

The remainder of the paper is organized as follow: Section 2 reviews the background of bank ownership and economic stimulus package in China and develops our main hypotheses; Section 3 describes the data and methodology; Section 4 reports our empirical evidence; and Section 5 concludes.

\section{Institutional background and hypothesis development}

\subsection{Bank ownership in China}

The Chinese banking industry reform was launched by the government from the late $1970 s^{1}$. In the early 1980s, the government established four wholly state-owned banks (the Big Four), who took control of all the commercial banking functions of the People’s Bank of

\footnotetext{
${ }^{1}$ During this period, China also initiated economic reform aimed at transforming from a planned to a marketoriented economy.
} 
China (the central bank). Later on in 1994, three wholly state-owned policy banks ${ }^{2}$ were established and took over the policy lending functions from the Big Four banks, and it was from that time that joint stock commercial banks and city banks began to emerge in China. Because China is featured as lacking a public bond market and placing a heavy reliance on bank borrowing, during the early 1990s these banks were the only type of financial institutions in the market and as such were actively involved in providing capital for corporate sector growth, but under supervision from the People's Bank of China.

During the same period, and starting from the early 1990s, two stock exchanges were established in Shanghai and Shenzhen and many SOEs undertook reform to become listed on either of these stock exchanges. According to the regulations of the central bank, commercial banks were encouraged to participate in the sponsorship and underwriting business of initial public offerings (IPO) of these listed SOEs (Cao, 2008), to become initial shareholders of these IPO firms. In this sense these bank ownerships were formed before these listed firms began to trade publicly. In 1995 the Commercial Bank Law (revised in 2003) clearly prohibited commercial banks from holding new ownership in non-financial companies without special permission from the authorities.

The law not only prohibited banks from holding equity of listed firms, it also prevented commercial banks from becoming shareholders of listed firms through other channels, such as becoming the legal shareholders of firms who defaulted on their loans, or through the debtfor-equity swap. Although banks can no longer become shareholders of listed companies through direct investment, it is worth noting that they can still exert an active influence through their existing ownership of the companies (Luo et al., 2011).

\subsection{Economic stimulus package}

Since the global financial crisis of 2007, many governments took measures to recover their economy by implementing economic stimulus packages. In response to the financial crisis the Chinese government also announced a 4 trillion RMB (about $\$ 586$ billion) economic stimulus package which accounted for 12.5\% of total GDP in 2008, spending from the fourth quarter 2008 to 2010. The stimulus package refers to investment spending, which was officially announced on $5^{\text {th }}$ November 2008. Of the total 4 trillion RMB plan the central government directly committed a fund of 1.18 trillion RMB of the investment, which was $30 \%$ of the overall program, while the rest was funded by local governments and banks. In reality the disbursement of central government stimulus spending included six tranches.

\footnotetext{
${ }^{2}$ These are State Development Banks, the Agricultural Development Bank of China and the Export and Import Bank of China.
} 
Altogether, the central government input to the stimulus totalled 1.6 trillion which is more than what was planned originally. Meanwhile, local governments actively echoed the central stimulus program which accounted for $70 \%$ to $75 \%$ of budgetary expenditures on fixed investment. Among the 34 administrative regions in China, 24 regions announced respective investment plans. For example, Yunnan and Liaoning provinces announced 3 trillion and 1.3 trillion RMB investment plans, respectively. The economic stimulus package was not only involved in expanding government investment plans by focussing mainly on transportation and infrastructure programs, it also accelerated bank loans lent to firms, particularly SOEs. Thus, the economic stimulus package had a direct influence on lending decisions and firm investment policies. The implementation of this economic stimulus package suggests that government intervention affects lending decisions and firm investment policies, which enables us to add new evidence to the literature.

\subsection{Hypothesis development}

Our first hypothesis relates to banks' ex ante monitoring for their lending decisions. There is a growing body of literature on the practice of bank lending where academics focus on whether banks make optimal lending decisions or efficient capital allocation. China has an underdeveloped financial system and lack a public bond market, which means that banks are the main providers of capital while bank credits are scarce (Cull and $\mathrm{Xu}, 2000$ ). Because the Chinese banking industry is controlled mainly by the state, because of the policy factors and homogeneity of state ownership, these state owned banks have a propensity to lend to SOEs regardless of their profitability (Cull and Xu, 2003; Firth et al., 2009). Moreover, bank ownership may facilitate SOEs to easier access to more bank loans. In addition, in the context of China, non-SOEs face being discriminated against access to bank loans and try to survive and sustain their growth, and they have incentives to seek external financing support by establishing connections with banks (Li et al., 2008; Firth et al., 2009). As a form of bankfirm connection, bank ownership may help non-SOEs to get bank loans more readily. Following the existing evidence that banks allocate capital to financially healthier non-SOEs using commercial judgements (Firth et al., 2009; Chen et al., 2013), we expect that bank ownership helps non-SOEs to achieve better firm performance based on which more bank loans will be awarded. Therefore, we have the following hypothesis:

H1: Bank ownership reduces the bank lending efficiency for SOEs, and enhances bank lending efficiency for non-SOEs 
Our next hypothesis relates to banks' ex post monitoring and examines how bank ownership affects subsequent firm investment policy. A large body of literature provides evidence that conflicts of interest between shareholders and lenders exerts influence on firm investment and creates incentives to deviate from optimal investment policies ${ }^{3}$. Meanwhile, literature regarding bank ownership argues that permitting banks to hold equity of nonfinancial companies can mitigate or even eliminate the conflict which may lead to optimal investment. This hypothesis intends to investigate how bank ownership affects investment policy and whether the effects of bank ownership are consistent across both SOEs and nonSOEs. Extant evidence argues that banks are reluctant to play effective monitoring roles in emerging markets as they do in developed markets (Barth et al., 2006). In China, more than $90 \%$ of the banking assets are owned and controlled by the state, and the financial system is dominated by state ownership and most firm borrowings are supported by bank loans (Firth et al., 2008). State owned banks follow the objectives set by politicians and bureaucrats to serve both political and economic objectives, and they tend to have lending behaviours that allocate and price loans according to the preferences and priorities of governments (Cull and $\mathrm{Xu}$, 2000). State owned banks are obliged to lend largely to SOEs in order to maintain normal economic growth and achieve social goals (Cull and Xu, 2005; Allen et al., 2005). The homogeneity of state ownership at both bank-level and firm-level leads to a positive lending bias to SOEs (Firth et al., 2008), which creates less incentives for banks to extend monitoring and encourages SOEs to engage in sub-optimal investments. Furthermore, if banks also hold ownership of SOEs, which indicates a better and more stable bank relationship, these SOEs are more favoured by state-owned bank lending which may eventually affect the efficiency of capital allocation and distort firm investment decisions (Firth et al., 2008; Lin et al., 2009). In this sense we conjecture that bank ownership may not exercise effective monitoring over firm investment efficiency for SOEs.

Although we anticipate a negative impact of bank ownership on investment efficiency for SOEs, this effect could be different for non-SOEs. Non-SOE listed firms evolved since 2001 and they are comparable in many ways to their counterparts in developed economies where value maximization is the dominating objective (Allen et al., 2005; Chen et al., 2011). In non-SOEs, bank ownership faces an apparent conflict of interest and is likely to extend monitoring functions, which may influence firm investment in favour of their own interest of liability quality (Lin et al., 2009). As bank ownership is effective to alleviate asymmetric

\footnotetext{
${ }^{3}$ The asset-substitution problem (Jensen and Meckling, 1976), the underinvestment problem (Myers, 1977), and the overinvestment problem (Stulz, 1990) are well-known examples of such distortions of investment policy.
} 
information and agency problems (Kroszner and Strahan, 2001), bank ownership in turn will overcome the distortions to optimal investment choices induced by capital market imperfections (Chen et al., 2011). Consistent with our discussion, we construct our hypothesis as follow:

H2: Bank ownership reduces investment efficiency for SOEs, while enhances investment efficiency for non-SOEs

\section{Sample selection and methodology}

\subsection{Sample selection}

Our sample data are obtained from the Chinese Stock and Market Accounting Research database (CSMAR) from 2003 to 2010 for all of listed firms on both the Shanghai and Shenzhen stock exchanges. We start our sample from 2003 because the new accounting and auditing standards were applied in China in 2002. Following common practice, we delete financial firms and firms flagged with ST or ST*. We also exclude firm-year observations with missing information on the variables that are used in this study. Finally, our sample consists of 1,073 firms and 8,476 firm-year observations.

\subsection{Bank ownership}

We manually collect the information on bank ownership by following the steps described below. First, from the Corporate Governance database of CSMAR, we are able to assemble detailed information on the top ten largest shareholders and the ownership holding by each of these top ten largest shareholders in the firms. We then identify that whether one of the top ten largest shareholders is a bank. We then go through the IPO prospectus of the companies with bank ownership and ensure that commercial banks were among the original sponsors and shareholders in the IPO of these listed firms. To ensure the objective of bank ownership holding, we exclude the bank ownership obtained from the debt-to-equity swap in SOEs reform, which is consistent with Lin et al. (2009) and Luo et al. (2011). We apply two proxies for bank ownership. The first measure is a dummy variable Bankdummy, which is equal to 1 if at least one of the top ten largest shareholders is a bank and 0 otherwise. The second measure is Bankshare which is the percentage of shares held by bank shareholders. Table 1 reports a detailed summary of bank ownership in China's listed firms over our sample by year. Table 1 reveals there are 498 firm-year observations with bank shareholder out of the 8,496 firm-year observations. From Table 1 we find that the total number of firms with bank as the shareholder decreases and the corresponding percentage also decreases over time from 
$88(8.71 \%)$ in 2003 to $50(4.83 \%)$ in 2010 . These results are comparative with the data reported by Lin et al. (2009) and Luo et al. (2011).

Table 1. Summary of bank ownership

\begin{tabular}{cccc}
\hline Year & Total & Firms with bank ownership & Percentage of bank ownership \\
\hline 2003 & 1,010 & 88 & $8.71 \%$ \\
2004 & 1,096 & 80 & $7.30 \%$ \\
2005 & 1,095 & 77 & $7.03 \%$ \\
2006 & 1,082 & 51 & $4.71 \%$ \\
2007 & 1,013 & 51 & $5.03 \%$ \\
2008 & 1,078 & 51 & $4.73 \%$ \\
2009 & 1,068 & 50 & $4.68 \%$ \\
2010 & 1,034 & 50 & $4.83 \%$ \\
Total & 8,476 & 498 & $5.88 \%$ \\
\hline
\end{tabular}

\subsection{Other variables}

To remain consistent with most extant literature, we obtain the information from the balance sheet and we use the ratio of total bank loans to total debt as the proxy for firms' access to bank loans. As previous studies suggest that banks should extend credits to profitable firms, we use the sensitivity of bank loan granted to firm profitability as the proxy for bank lending efficiency, where we apply the return on sales (ROS) as the measure for firm profitability, following Firth et al. (2009) and Chen et al. (2013). In addition, we select the financial information from the cash flow statements and measure investment expenditure for a firm as the ratio of net capital expenditure (the capital expenditure less depreciation) to net fixed assets, as used by Lang et al. (1996), Aivazian et al. (2005) and Firth et al. (2008). Empirically, a firm's investment should be solely determined by the profitability of its investment as measured by Tobin's Q (Chen et al., 2011), given Q as a summary of statistics for the market's information about investment opportunities. In this paper we apply the relationship between investment expenditure and Tobin's Q as the measure of investment efficiency. In the multivariate analysis, we also include a set of control variables which have been proved to have an effect on bank lending decisions and firm investment expenditures. All of the variables used in this study are shown in Table 2.

Table 2. Variable and definitions

\begin{tabular}{ll}
\hline Variable & Definitions \\
\hline Bankdummy & Equal 1 for firm-year observations if the bank is holding ownership of the firm \\
Bankshare & Percentage of shares held by the bank shareholders \\
Bankloan & Bank loans / Total debt \\
Investment & (Capital expenditure-depreciation) / Net fixed assets \\
ROA & Net income / Total assets \\
ROS & Net income / Sales \\
Leverage & Bank loans / Total assets \\
Income & Net income + depreciation / Total assets \\
Tobin's Q & Market value / Replacement value \\
Size & Log of total assets \\
Sales & Sales / Total assets \\
Tangibility & Tangible assets / Total assets \\
\hline
\end{tabular}




\begin{tabular}{ll}
\hline Board & Number of total directors on the boards \\
Indep & Number of independent directors / Total number of directors on board \\
Largest & Ownership of the largest shareholder for each firm \\
Political & Equal 1 for firms with politically connected executives or large shareholders \\
\hline
\end{tabular}

\section{Empirical results}

\subsection{Summary statistics}

We present summary statistics of bank ownership, investment expenditures, and firm characteristics in Table 3. As Table 3 shows, we find that there are 5.88\% of total firm-year observations with banks as the shareholders, and the average bank ownership is $0.13 \%$ with a maximum of $26.82 \%$. We also present that the average bank loan to total debt ratio is $48.11 \%$ over our sample. The mean (median) of the ratio of net investment to fixed assets is $28.88 \%$ (15.16\%), which is close to the 34.1\% (14.8\%) reported by Firth et al. (2008). The sample average Tobin's $\mathrm{Q}$ is 1.62 and the median value is 1.18 , and the average internal cash flow ratio is $4.75 \%$ which is similar to that reported in Euro zone of 3.9\% by Pindado et al. (2011).

Table 3. Summary statistics

\begin{tabular}{llllllll}
\hline & Mean & Median & Min & Lower quartile & Higher quartile & Max & Obs \\
\hline Bankdummy & $5.88 \%$ & 0 & 0 & 0 & 0 & 1 & 8476 \\
Bankshare (\%) & 0.13 & 0 & 0 & 0 & 0 & 26.82 & 8476 \\
Bankloan (\%) & 48.11 & 49.29 & 0 & 28.26 & 65.45 & 99.88 & 8476 \\
Investment (\%) & 28.88 & 15.16 & -9.86 & 6.20 & 28.47 & 306.33 & 8476 \\
ROA (\%) & 2.63 & 2.74 & -68.26 & 0.84 & 5.39 & 46.31 & 8476 \\
ROS (\%) & 5.47 & 4.45 & -29.61 & 1.47 & 10.03 & 69.39 & 8476 \\
Leverage (\%) & 51.56 & 51.78 & 0.02 & 38.23 & 63.86 & 89.88 & 8476 \\
Income (\%) & 4.75 & 5.08 & -8.70 & 2.93 & 8.19 & 11.48 & 8476 \\
Tobin's Q & 1.62 & 1.18 & 0.49 & 1.02 & 1.56 & 16.89 & 8476 \\
Firm size (million) & 6,230 & 2,190 & 27.3 & 1,130 & 4,490 & 98,500 & 8476 \\
Sales (\%) & 72.03 & 56.75 & 0.95 & 34.84 & 87.27 & 100.03 & 8476 \\
Tangibility (\%) & 29.86 & 27.28 & 0.20 & 15.69 & 42.98 & 157.48 & 8476 \\
Board & 8.75 & 9 & 0 & 7 & 10 & 23 & 8476 \\
Indep (\%) & 0.41 & 0.36 & 0 & 0.33 & 0.5 & 0.75 & 8476 \\
Largest (\%) & 46.32 & 40.77 & 1.73 & 27.13 & 58.25 & 85.23 & 8476 \\
Political & 0.43 & 0 & 0 & 0 & 1 & 1 & 8476 \\
\hline This table provides
\end{tabular}

This table provides summary statistics of our sample. Bankdummy is a dummy variable equal to 1 if the firm has a bank as the shareholder. Bankshare is the percentage of ownership held by bank shareholder. Bankloan is the ratio of total bank loans to total debt value. Investment is the ratio of net capital expenditure to total fixed assets. ROA is the return on assets, measured as the ratio of net income to total assets. ROS is the return on sales, measured as the ratio of net income to total sales. Leverage is the ratio of bank loans to total assets. Income is the ratio of internal cash flow to total assets. Tobin's Q is the ratio of firm market value to replacement value. Firm size is firm total assets. Sale is the ratio of sales to total assets. Tangibility is the ratio of tangible assets to total assets. Board is the number of total directors on the board. Indep is the ratio of independent directors to total directors on the board. Largest is the percentage of ownership held by the largest shareholder. Political is a dummy variable, equal 1 for politically connected firms.

\subsection{Empirical results}

\subsubsection{Univariate tests}

To provide some empirical evidence to support our hypotheses we conduct the following univariate tests by comparing the bank loans, investments, firm performance and firm 
characteristics for firms with and without bank ownership, and the results are reported in Table 4. In Table 4 we compare the mean of our key variables between firms with and without bank ownership. Our tests cover the full sample as well as both SOE and non-SOE sub-samples. For the full sample we find that bank ownership facilitates capital flows and the bank loan ratio is $50.92 \%$ for firms with bank ownership, which is significantly higher than 46.05\% for firms without bank ownership, and firms with bank ownership have a lower ROS (4.12\%) compared with firms without bank ownership (5.55\%). We also find that firms with bank ownership have significantly higher mean investment expenditures $(31.24 \%$ vs. 25.19\%) but lower mean Tobin's Q (1.38 vs. 1.60) than firms without bank ownership. For the SOE sub-sample we find that the bank loan ratio is significantly higher and ROS is significantly lower for firms with bank ownership than those for firms without bank ownership. We also observe no significant difference in investment expenditure, but firms with bank ownership have a significantly lower Tobin's Q than firms without bank ownership. As for the non-SOE sub-sample, we present that firms with bank ownership have both a higher bank loan ratio and ROS than those firms without bank ownership. We further find that both investment expenditure and Tobin's Q are higher for firms with bank ownership than those firms without bank ownership.

In addition to the differences in the level of bank loans, investment expenditures and Tobin's Q, there are also significant differences in accounting-based firm performance (ROA and ROS). In particular, firm performance is significantly lower in firms with bank ownership for the full sample and SOE sub-sample, while significantly higher in firms with bank ownership for the non-SOE sub-sample. For example, for the full sample the ROA is $1.57 \%$ for firms with bank ownership which is significantly lower than $2.40 \%$ for firms without bank ownership (t-value is -2.64). We also observe significant differences in control variables from Table 4, suggesting the need to control for these variables in analysing investment efficiency.

Table 4. Univariate tests

\begin{tabular}{|c|c|c|c|c|c|c|c|c|c|}
\hline & \multicolumn{3}{|c|}{ Full sample } & \multicolumn{3}{|c|}{ SOES } & \multicolumn{3}{|c|}{ Non-SOEs } \\
\hline & With & Without & t-value & With & Without & t-value & With & Without & t-value \\
\hline $\begin{array}{l}\text { Bankloan } \\
\text { (\%) }\end{array}$ & 50.92 & 46.05 & $\begin{array}{l}4.87 * * * \\
(2.89)\end{array}$ & 50.70 & 45.93 & $\begin{array}{l}4.77 * * * \\
(2.66)\end{array}$ & 51.22 & 47.07 & $\begin{array}{l}4.15^{* * *} \\
(2.91)\end{array}$ \\
\hline $\begin{array}{l}\text { Investment } \\
\text { (\%) }\end{array}$ & 31.24 & 25.19 & $\begin{array}{l}6.05^{* * *} \\
(2.73)\end{array}$ & 32.76 & 29.31 & $\begin{array}{l}3.45 \\
(1.28)\end{array}$ & 29.20 & 24.19 & $\begin{array}{l}5.01 * * * \\
(2.62)\end{array}$ \\
\hline Tobin’s Q & 1.38 & 1.60 & $\begin{array}{l}-0.22 * * * \\
(-3.56)\end{array}$ & 1.12 & 1.55 & $\begin{array}{l}-0.43^{* * *} \\
(-4.28)\end{array}$ & 1.81 & 1.63 & $\begin{array}{l}0.18^{* *} \\
(2.56)\end{array}$ \\
\hline ROA (\%) & 1.57 & 2.40 & $\begin{array}{l}-0.83^{* *} \\
(-2.64)\end{array}$ & 1.46 & 2.53 & $\begin{array}{l}-1.07^{* *} \\
(-2.83)\end{array}$ & 2.47 & 1.78 & $\begin{array}{l}0.69 * * \\
(2.02)\end{array}$ \\
\hline ROS (\%) & 4.12 & 5.55 & $\begin{array}{l}-1.43^{* *} \\
(-2.02)\end{array}$ & 3.85 & 5.73 & $\begin{array}{l}-1.88 * * * \\
(-2.71)\end{array}$ & 5.95 & 5.09 & $\begin{array}{l}0.86^{*} \\
(1.85)\end{array}$ \\
\hline
\end{tabular}




\begin{tabular}{|c|c|c|c|c|c|c|c|c|c|}
\hline $\begin{array}{l}\text { Assets } \\
\text { (million) }\end{array}$ & 9,530 & 5,610 & $\begin{array}{l}3,920 * * \\
(2.23)\end{array}$ & 11,400 & 6,750 & $\begin{array}{l}4,650 * * \\
(1.97)\end{array}$ & 4,080 & 2,790 & $\begin{array}{l}1,290^{* *} \\
(2.31)\end{array}$ \\
\hline $\begin{array}{l}\text { Tangibility } \\
\text { (million) }\end{array}$ & 4,270 & 2,030 & $\begin{array}{l}2,240 * * \\
(2.17)\end{array}$ & 5,340 & 2,580 & $\begin{array}{l}2,760 * * \\
(1.99)\end{array}$ & 1,200 & 662 & $\begin{array}{l}538 * * \\
(2.42)\end{array}$ \\
\hline $\begin{array}{l}\text { Leverage } \\
\text { (\%) }\end{array}$ & 53.17 & 49.97 & $\begin{array}{l}3.20^{* *} \\
(2.24)\end{array}$ & 49.85 & 50.81 & $\begin{array}{l}-0.96 \\
(-0.84)\end{array}$ & 58.87 & 51.35 & $\begin{array}{l}7.52^{* * *} \\
(4.47)\end{array}$ \\
\hline $\begin{array}{l}\text { Income } \\
\text { (\%) }\end{array}$ & 3.91 & 4.78 & $\begin{array}{l}-0.87 \\
(-1.32)\end{array}$ & 4.51 & 5.37 & $\begin{array}{l}-0.86 \\
(-1.06)\end{array}$ & 2.17 & 3.30 & $\begin{array}{l}-1.13 \\
(-1.16)\end{array}$ \\
\hline $\begin{array}{l}\text { Sales } \\
(\%)\end{array}$ & 67.61 & 70.67 & $\begin{array}{l}-3.06 \\
(-1.23)\end{array}$ & 70.80 & 73.59 & $\begin{array}{l}-2.79 \\
(-0.99)\end{array}$ & 58.40 & 63.42 & $\begin{array}{l}-5.02 \\
(-0.97)\end{array}$ \\
\hline Board & 9.15 & 8.72 & $\begin{array}{l}0.43^{* * *} \\
(3.33)\end{array}$ & 9.43 & 8.96 & $\begin{array}{l}0.47^{* * * *} \\
(3.19)\end{array}$ & 8.31 & 8.12 & $\begin{array}{l}0.19 \\
(0.79)\end{array}$ \\
\hline Indep (\%) & 39.24 & 41.57 & $\begin{array}{l}-2.33^{* * *} \\
(-3.09)\end{array}$ & 38.08 & 40.84 & $\begin{array}{l}-1.76 * * * \\
(-3.52)\end{array}$ & 42.57 & 43.39 & $\begin{array}{l}-0.82 \\
(-0.45)\end{array}$ \\
\hline Largest (\%) & 46.24 & 48.51 & $\begin{array}{l}-1.27 * * * \\
(-3.19)\end{array}$ & 38.76 & 41.26 & $\begin{array}{l}-2.50 * * * \\
(-2.90)\end{array}$ & 28.96 & 31.72 & $\begin{array}{l}-2.76^{* * *} \\
(-2.82)\end{array}$ \\
\hline Political & 36.50 & 43.68 & $\begin{array}{l}-7.18^{* * *} \\
(-3.10)\end{array}$ & 41.23 & 47.78 & $\begin{array}{l}-6.55^{* *} \\
(-2.38)\end{array}$ & 23.15 & 33.43 & $\begin{array}{l}-10.28 * * \\
(-2.56)\end{array}$ \\
\hline
\end{tabular}

\subsubsection{Bank ownership and bank lending efficiency}

In this section we conduct a multivariate analysis to examine the effect of bank ownership on bank lending efficiency, by estimating the following equation:

$$
\begin{aligned}
\text { Bankloan }_{i t}= & \alpha_{0}+\alpha_{1} \text { Bank }_{i t-1}+\alpha_{2} \text { Bank }_{i t-1} * \text { ROS }_{i t-1}+\alpha_{3} \text { ROS }_{i t-1}+\alpha_{4} Q_{i t-1} \\
& +\alpha_{5} \text { Size }_{i t}+\alpha_{6} \text { Tangibility }_{i t}+\alpha_{7} \text { Political }_{i t}+\alpha_{8} \text { Board }_{i t} \\
& +\alpha_{9} \text { Indep }_{i t}+\varepsilon_{i t}
\end{aligned}
$$

where Bankloan is the ratio of total bank loans to total debt level, which is the proxy for the firm's access to bank loans. Bank is the measurement of bank ownership. We apply two proxies in the regression respectively. One is the dummy variable Bankdummy, which is equal to 1 if the firm has a bank shareholder. Another is Bankshare which is the percentage of shares held by bank shareholders. ROS is return on sales which is the proxy for firm performance. $Q$ is the value of Tobin's $Q$ calculated as the ratio of firm market value to replacement value, which is used to proxy for the firm investment opportunity (Firth et al., 2008; Chen et al., 2011). Size is the log of firm total assets. Tangibility is the ratio of tangible assets to firm total assets. Political is a dummy variable if the firm is politically connected. Board is the log of the total number of directors on the boards. Indep is the ratio of independent directors to total directors on the boards. We also include year and industry fixed effects. Following previous studies, we use the one year lag of bank ownership, firm performance and Tobin's Q in the regression. Table 5 reports our regression results.

Table 5. Effect of bank ownership on bank lending efficiency

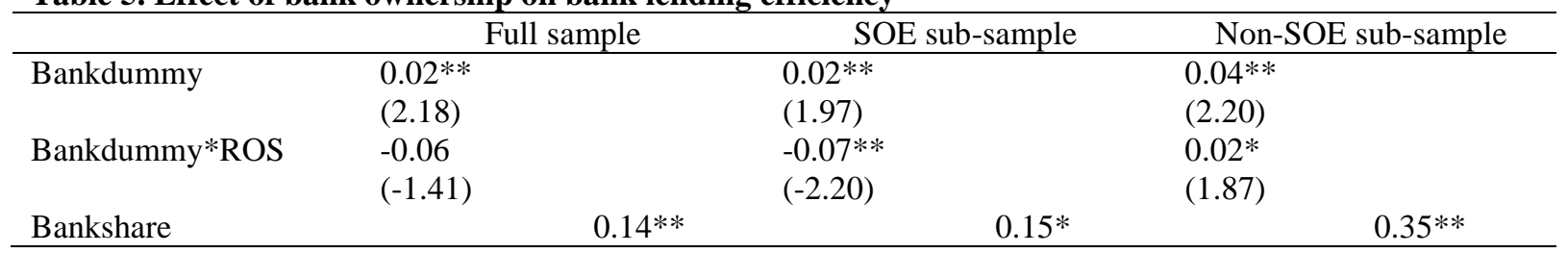




\begin{tabular}{|c|c|c|c|c|c|c|}
\hline \multirow{2}{*}{\multicolumn{2}{|c|}{ Bankshare*ROS }} & \multirow{2}{*}{\multicolumn{2}{|c|}{$\begin{array}{l}(2.06) \\
-0.03^{*} \\
(-1.71)\end{array}$}} & \multirow{2}{*}{\multicolumn{2}{|c|}{$\begin{array}{l}(1.77) \\
-0.03^{* *} \\
(-2.22)\end{array}$}} & \multirow{3}{*}{$\begin{array}{l}(2.41) \\
0.02 * \\
(1.92) \\
0.03^{* *}\end{array}$} \\
\hline & & & & & & \\
\hline ROS & $\begin{array}{l}0.05^{* * *} \\
(2.65)\end{array}$ & $\begin{array}{l}0.05^{* * *} \\
(2.62)\end{array}$ & $\begin{array}{l}0.06^{* * *} \\
(2.76)\end{array}$ & $\begin{array}{l}0.06^{* * *} \\
(2.70)\end{array}$ & $\begin{array}{l}0.03^{* *} \\
(2.29)\end{array}$ & \\
\hline Q & $\begin{array}{l}0.02^{* * *} \\
(6.22)\end{array}$ & $\begin{array}{l}0.02^{* * *} \\
(6.21)\end{array}$ & $\begin{array}{l}0.02 * * * \\
(3.52)\end{array}$ & $\begin{array}{l}0.02^{* * *} \\
(3.50)\end{array}$ & $\begin{array}{l}0.02^{* * *} \\
(4.01)\end{array}$ & $\begin{array}{l}0.02 * * * \\
(4.01)\end{array}$ \\
\hline Size & $\begin{array}{l}0.02^{* * *} \\
(4.48)\end{array}$ & $\begin{array}{l}0.02^{* * *} \\
(4.52)\end{array}$ & $\begin{array}{l}0.02 * * * \\
(3.69)\end{array}$ & $\begin{array}{l}0.02^{* * *} \\
(3.72)\end{array}$ & $\begin{array}{l}0.03^{* * *} \\
(2.94)\end{array}$ & $\begin{array}{l}0.03^{* * * *} \\
(2.93)\end{array}$ \\
\hline Tangibility & $\begin{array}{l}0.17^{* * *} \\
(8.27)\end{array}$ & $\begin{array}{l}0.17 * * * \\
(8.28)\end{array}$ & $\begin{array}{l}0.15^{* * *} \\
(6.21)\end{array}$ & $\begin{array}{l}0.15^{* * *} \\
(6.19)\end{array}$ & $\begin{array}{l}0.20^{* * *} \\
(4.60)\end{array}$ & $\begin{array}{l}0.20^{* * *} \\
(4.60)\end{array}$ \\
\hline Political & $\begin{array}{l}0.02^{* * *} \\
(2.57)\end{array}$ & $\begin{array}{l}0.02^{* *} \\
(2.55)\end{array}$ & $\begin{array}{l}0.01^{* *} \\
(2.03)\end{array}$ & $\begin{array}{l}0.01^{* *} \\
(2.00)\end{array}$ & $\begin{array}{l}0.03^{* *} \\
(2.47)\end{array}$ & $\begin{array}{l}0.03^{* * *} \\
(2.46)\end{array}$ \\
\hline Board & $\begin{array}{l}0.01 \\
(0.96)\end{array}$ & $\begin{array}{l}0.01 \\
(0.95)\end{array}$ & $\begin{array}{l}0.01 \\
(1.09)\end{array}$ & $\begin{array}{l}0.01 \\
(1.05)\end{array}$ & $\begin{array}{l}0.01 \\
(0.36)\end{array}$ & $\begin{array}{l}0.01 \\
(0.36)\end{array}$ \\
\hline Indep & $\begin{array}{l}-0.03^{* *} \\
(-1.99)\end{array}$ & $\begin{array}{l}-0.03^{* *} \\
(-2.00)\end{array}$ & $\begin{array}{l}-0.03^{*} \\
(-1.66)\end{array}$ & $\begin{array}{l}-0.03^{*} \\
(-1.69)\end{array}$ & $\begin{array}{l}-0.03 \\
(-1.13)\end{array}$ & $\begin{array}{l}-0.03 \\
(-1.12)\end{array}$ \\
\hline Constant & $\begin{array}{l}-0.05 \\
(-0.46)\end{array}$ & $\begin{array}{l}-0.05 \\
(-0.49)\end{array}$ & $\begin{array}{l}-0.05 \\
(-0.40)\end{array}$ & $\begin{array}{l}-0.05 \\
(-0.41)\end{array}$ & $\begin{array}{l}-0.19 \\
(-0.85)\end{array}$ & $\begin{array}{l}-0.19 \\
(-0.85)\end{array}$ \\
\hline Year fixed effects & Included & Included & Included & Included & Included & Included \\
\hline Industry fixed effects & Included & Included & Included & Included & Included & Included \\
\hline Sum tests ${ }^{a}$ & $4.52 * * *$ & $4.66 * * *$ & $4.41 * * *$ & $3.48 * * *$ & $3.39 * * *$ & $3.69 * * *$ \\
\hline Adjusted $\mathrm{R}^{2}$ & 0.31 & 0.32 & 0.25 & 0.25 & 0.40 & 0.40 \\
\hline Observations & 8476 & 8476 & 5939 & 5939 & 2537 & 2537 \\
\hline
\end{tabular}

${ }^{a}$ Reports the significance tests of the sum of the estimated coefficients between ROS and Bankdummy*ROS, and between ROS and Bankshare*ROS in each regression.

Dependent variable is the ratio of bank loans to total debt level of the firm. Bankdummy is a dummy variable equal to 1 if the firm has a bank shareholder and 0 otherwise. Bankshare is the percentage of shares held by bank shareholders. ROS is the return on sales. $\mathrm{Q}$ is the ratio of firm market value to replacement value. Size is the log of firm total assets. Tangibility is the ratio of firm's tangible assets to total assets. Political is a dummy variable equal to 1 if the firm is politically connected. Board is the log of number of total directors on the boards. Indep is the ratio of independent directors to total directors on the boards.

Table 5 reports our models and we observe that both measurements of bank ownership are significantly and positively related to the bank loan ratio. This results hold irrespective of ownership structure and are consistent for both SOEs and non-SOEs. In the spirit of previous studies (Firth et al., 2009), we apply the relationship between the bank loan ratio and firm performance as an indication of whether banks make optimal lending decisions, and a positive relationship between the bank loan ratio and firm performance suggests efficient lending. When we turn to interaction terms between bank ownership and ROS, more evidence emerges. For the full sample, the estimated coefficients on both Bankdummy*ROS and Bankshare*ROS are negative, suggesting that bank ownership may distort bank lending decisions. In addition, for both the SOE and non-SOE sub-samples, we find that the attenuating effect of bank ownership on bank lending efficiency is more pronounced for SOEs, indicating less monitoring functions exercised by bank ownership in SOEs. However for non-SOEs, the estimated coefficients on interaction terms are positive and statistically significant, suggesting that unlike SOEs, bank ownership is more likely to extend effective monitoring for non-SOEs and can help financially healthier non-SOEs to get more bank 
loans. We also report the significance of the sum tests in the table with the results suggesting that our findings are statistically significant. For example in column 5 for non-SOEs, the sum test is 3.69 significant at the $1 \%$ level, suggesting that for non-SOEs, the estimated coefficient on ROS is $0.05(0.02+0.03)$ and the banks exercise efficient lending to non-SOEs. Overall, our findings from Table 5 suggest that bank ownership exercises less monitoring and reduces bank lending efficiency for SOEs, while bank ownership is effective in monitoring bank lending efficiency for non-SOEs. We also find that return on sales (ROS) is positively related to the bank loan ratio across all six specifications. This result is consistent with those obtained by previous studies that banks tend to allocate loans to profitable firms using their commercial judgements (Cull and Xu, 2005; Firth et al., 2009; Zheng and Zhu, 2013). Among the control variables we find that political connection facilitates firm's access to bank loans, which is consistent with most previous studies (Li et al., 2008; Faccio, 2010). As a robustness test, we also apply another two measurements. One is the change in the bank loan ratio between the current and previous year, and the other one is a dummy variable equal to 1 if the firm has outstanding bank loans. We also replace ROS with ROA (return on assets) in the regression and we obtain similar results.

\subsubsection{Bank ownership and firm investment efficiency}

In the following section we conduct multivariate analysis to examine the effect of bank ownership on investment efficiency, by estimating the following equation:

$$
\begin{aligned}
\text { Investment }_{i t}= & \alpha_{0}+\alpha_{1} \text { Bank }_{i t-1}+\alpha_{2} \text { Bank }_{i t-1} * Q_{i t-1}+\alpha_{3} Q_{i t-1}+\alpha_{4} \text { Leverage }_{i t-1} \\
& +\alpha_{5} \text { Income }_{i t}+\alpha_{6} \text { Size }_{i t}+\alpha_{7} \text { Sale }_{i t-1}+\alpha_{8} \text { Tangibility }_{i t}+\varepsilon_{i t}
\end{aligned}
$$

where Investment is a firm's investment expenditures. Existing studies also applied other proxies for investment which we will consider for the robustness tests ${ }^{4}$. Leverage is defined as the proportion of bank loans of total assets. Income is used to measure internal funds available for investments, which is measured as the ratio of net income plus depreciation to total assets. We follow prior studies to control for the rate of sales growth. In particular, Sale is the net sales scaled by total assets. We also include year and industry fixed effects. To remain consistent with the extant literature we use the one year lag of leverage, Tobin's Q value, and sales level in the regression.

Table 6 shows the regression results of the effect of bank ownership on firm investment efficiency, measured as the sensitivity of investment expenditures to investment opportunities

\footnotetext{
${ }^{4}$ These measures include (1) the ratio of change in net fixed assets plus deprecation to total net fixed assets (Pindado et al., 2011; Firth et al., 2012), (2) ratio of cash payments for fixed assets, intangible assets and other long-term assets less cash receipts from selling these assets to total assets (Chen et al., 2011).
} 
for full sample as well as both the SOEs and non-SOE sub-samples. As can be seen from Table 6 for the full sample, the estimated coefficients on both proxies for bank ownership are positive in both regressions, indicating that bank ownership encourages firm investment expenditures on average, and the effects are statistically significant (t-values are 2.62 and 2.09, respectively). When we divide our total sample into SOEs and non-SOEs, we find that the estimated coefficients on bank ownership are consistently positive and statistically significant for non-SOEs but become insignificant for SOEs, indicating that bank ownership has a more significantly positive effect on encouraging investment expenditures in non-SOEs, while bank ownership only matters marginally in SOEs. We are more concerned about the interaction terms between bank ownership and Tobin's Q in each regression and we observe some interesting evidence. For the full sample we observe negative and significant coefficients on Bankdummy*Q and Bankshare ${ }^{*} Q$ in both specifications, indicating that on average bank ownership reduces investment efficiency. In column 1 for instance the estimated coefficient on Bankdummy*Q is -0.03 and the t-value is -2.14 indicating that for every $1 \%$ change in Tobin's $\mathrm{Q}$, the change in investment is $3 \%$ lower for firms with bank ownership than for firms without bank ownership. We further divide our total sample into two groups of SOEs and non-SOEs and some interesting evidence emerge. For the SOE subsample, the effect of bank ownership on investment efficiency remains negative and statistically significant. For non-SOEs the bank ownership effect turns out to be positive, indicating that bank ownership can enhance the investment efficiency for non-SOEs. According to our hypothesis, bank ownership exerts less ex post monitoring on investment policy for SOEs than non-SOEs. .

In addition, in all the regressions we find that the coefficients on Leverage are negative and statistically significant at the $1 \%$ levels (except for SOE sub-sample). For example, in column 1 the coefficient on Leverage is -0.19 and the t-value is -4.35 . These results are consistent with previous studies that firm's leverage is negatively related to firm investment expenditures because it may either induce underinvestment (Myers, 1977) or reduce overinvestment (Stulz, 1990). Among other control variables, we also find that the estimated coefficients on Income are positive and statistically significant in all specifications, which is consistent with Pindado et al. (2011) who suggest that funds available to firms are positively related to firm investment decisions. We further find that firm size and tangible assets are both positively and significantly related to the investment, which echoes the findings by Aviazian et al. (2005) and Firth et al. (2008). The level of sales reflects the firm's growth prospects and the negative relationship between the sales level and investment is consistent 
with the findings of Aviazian et al. (2005) using the pooling regression. When we apply the fixed effect regression in the additional tests, the estimated coefficient on sales level turns out to be positive, indicating that firms generating higher revenue are likely to invest more. Overall, the results of our equation are consistent with previous evidence.

Table 6. Impact of bank ownership on investment efficiency

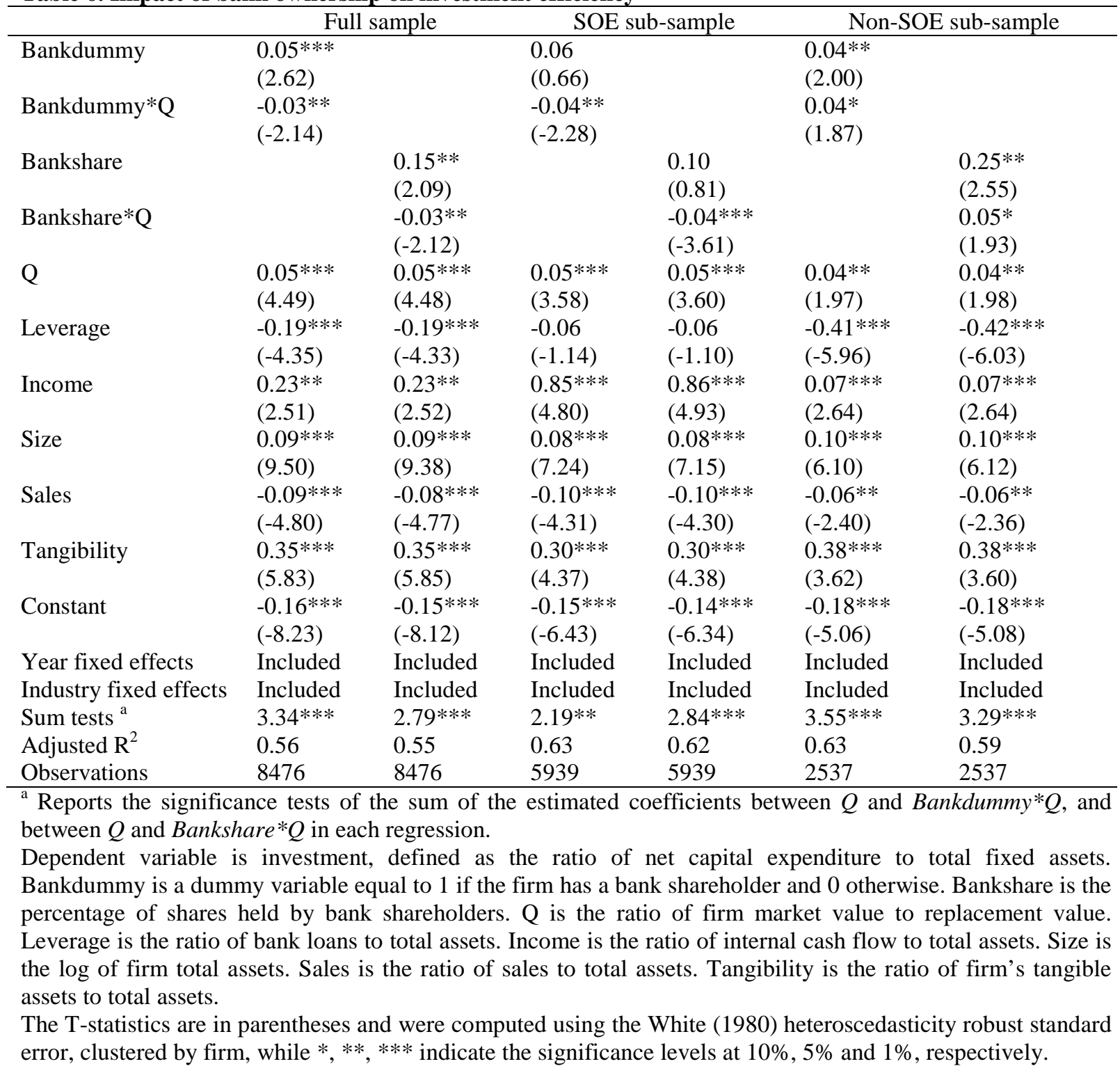

\subsection{Economic stimulus package and endogeneity issue}

As we describe before, commercial banks were encouraged to participate in the sponsorship and underwriting business of IPO of large SOEs, while since 1995, according to the Commercial Bank Law (revised in 2003), banks were prohibited from holding new ownership in non-financial companies. This indicates that bank ownership could not be increased but bank shareholders can also sell out their ownership due to observable and non- 
observable factors, so in this sense bank ownership suffers from an endogeneity issue. To address this problem we apply an economic stimulus package (ESP) as a natural experiment to test whether our results for correcting the endogeneity issue. We argue that an economic stimulus package is a relatively exogenous shock, at least with respect to any individual firm, that significantly increases the funds available on investment expenditures for firms. Holding bank ownership constant, this shock to the funds available increases the expected level of both lending level and investment expenditures. To provide some empirical evidence we repeat our above analysis by adding one dummy variable Package, which is equal to 1 for firm-year observations during the post-ESP period and 0 during the pre-ESP period, and the results are reported in Table 7 below.

In Panel A we repeat our equation (1) where the dependent variable is the ratio of bank loan to total debt value. From the results in Panel A we observe consistent coefficients on bank ownership and the interaction term between bank ownership and ROS that are as consistent as those in Table 5, and moreover, bank ownership has a positive coefficient in all specifications. The interaction term has a negative coefficient for the SOEs and a positive coefficient for the non-SOEs. We are more concerned about the interaction term between bank ownership, ROS and Package. For SOEs we find a negative and statistically significant coefficient, which indicate that after the economic stimulus package the SOEs with bank ownership are more likely to receive bank loans, regardless of their firm performance. For non-SOEs the positive coefficient suggests that bank ownership extends more efficient monitoring over their lending decisions to non-SOEs after the economic stimulus package.

In Panel B we report the results of our estimation of equation (2). As can be seen from Panel B, we find consistent estimated coefficients on our key variables of bank ownership and interaction terms between bank ownership and Tobin's Q, and the results are reported in Table 6. In Table 7 we are more concerned about any variables of Package and its interaction terms with bank ownership and Tobin's Q. Specifically, we observe insignificant coefficients on the Bankdummy*Package and Bankshare*Package in all the samples, suggesting that the bank ownership effect on investment expenditures does not change significantly before and after the economic stimulus package. As for the variables of both Bankdummy*Q*Package and Bankshare* ${ }^{*}$ Package, we find statistically negative coefficients for the full sample and SOEs, and positive coefficients for non-SOEs. For example, in column 1 the coefficients on Bankdummy*Q and Bank ${ }^{*} Q *$ Package are -0.02 and -0.01 significant at the 5\% level (t-values are -2.34 and -2.46 , respectively). These results indicate that bank ownership weakens the investment efficiency for SOEs while enhances investment efficiency for non-SOEs, and 
these effects have been reinforced after the introduction of the economic stimulus package. Our results suggest that low bank lending and investment efficiencies in SOE firms with bank ownership is exacerbated by the economic stimulus package implemented by the government. Overall, the results from Table 7 are consistent with the results from Table 6, which confirms that our results are robust for the correction of taking the endogeneity issue into account. In consistent with the previous tables, we also report the sum tests to test whether the sum of the estimated coefficients are also significant. From both Panel A and Panel B, we find that all the sum tests are significant, which suggests that our sum coefficients are also significant.

Table 7. Impact of bank ownership on investment efficiency: natural experiment method

\begin{tabular}{|c|c|c|c|c|c|c|}
\hline & & nple & SOE & -sample & Non-S & ub-sample \\
\hline Panel A: Dependent variable & bank loa & & & & & \\
\hline Bankdummy & $0.04 * *$ & & $0.03^{*}$ & & $0.05^{* *}$ & \\
\hline & $(2.19)$ & & $(1.95)$ & & $(2.45)$ & \\
\hline Bankdummy*ROS & -0.22 & & $-0.33^{* *}$ & & $0.14^{* *}$ & \\
\hline & $(-1.14)$ & & $(-2.27)$ & & $(2.00)$ & \\
\hline Bankdummy*Package & 0.01 & & 0.03 & & -0.06 & \\
\hline & $(0.31)$ & & $(0.95)$ & & $(-1.02)$ & \\
\hline Bankdummy*ROS*Package & -0.22 & & $-0.35 * *$ & & $0.08 *$ & \\
\hline & $(-1.44)$ & & $(-1.99)$ & & $(1.73)$ & \\
\hline Bankshare & & $0.25 * *$ & & $0.35^{*}$ & & $0.18^{* *}$ \\
\hline & & $(1.98)$ & & (1.69) & & $(2.30)$ \\
\hline Bankshare*ROS & & -0.07 & & $-0.12 * *$ & & $0.04 * *$ \\
\hline & & $(-1.13)$ & & $(-2.29)$ & & $(2.35)$ \\
\hline Bankshare*Package & & 0.77 & & $0.10 * *$ & & -0.04 \\
\hline & & $(1.50)$ & & $(2.07)$ & & $(-0.82)$ \\
\hline Bankshare*ROS*Package & & -0.06 & & $-0.03 *$ & & $0.02 *$ \\
\hline & & $(-1.60)$ & & $(-1.86)$ & & (1.84) \\
\hline Package & $0.05 * * *$ & $0.05 * * *$ & $0.04 * * *$ & $0.04 * * *$ & $0.07 * * *$ & $0.07 * * *$ \\
\hline & $(8.62)$ & (9.14) & (6.13) & $(6.41)$ & $(6.24)$ & (6.53) \\
\hline ROS & $0.11^{* * * *}$ & $0.10 * * *$ & $0.13^{* * *}$ & $0.12^{* * *}$ & $0.07 * * *$ & $0.07 * * *$ \\
\hline & (3.82) & (3.65) & (3.38) & (3.15) & (2.75) & $(2.81)$ \\
\hline
\end{tabular}

Other control variables include Tobin's Q, firm size, tangibility, political connection, board size, independent director ratio, year and industry fixed effects

\begin{tabular}{|c|c|c|c|c|c|c|}
\hline $\begin{array}{l}\text { Sum tests }{ }^{a} \\
\text { Adjusted } \mathrm{R}^{2} \\
\text { Observations }\end{array}$ & $\begin{array}{l}4.52^{* * *} \\
0.15 \\
8476\end{array}$ & $\begin{array}{l}5.33^{* * * *} \\
0.16 \\
8476\end{array}$ & $\begin{array}{l}4.21 * * * \\
0.13 \\
5939\end{array}$ & $\begin{array}{l}5.13 * * * \\
0.13 \\
5939\end{array}$ & $\begin{array}{l}6.98 * * * \\
0.28 \\
2537\end{array}$ & $\begin{array}{l}5.88 * * * \\
0.29 \\
2537\end{array}$ \\
\hline \multicolumn{7}{|c|}{ Panel B: Dependent variable is firm investment } \\
\hline Bankdummy & $\begin{array}{l}0.06 * * * \\
(2.86)\end{array}$ & & $\begin{array}{l}0.05^{* *} \\
(2.07)\end{array}$ & & $\begin{array}{l}0.06 * * * \\
(2.74)\end{array}$ & \\
\hline Bankdummy*Q & $\begin{array}{l}-0.02 * * \\
(-2.34)\end{array}$ & & $\begin{array}{l}-0.02 * * \\
(-2.38)\end{array}$ & & $\begin{array}{l}0.03^{*} \\
(1.93)\end{array}$ & \\
\hline Bankdummy*Package & $\begin{array}{l}0.05 \\
(1.16)\end{array}$ & & $\begin{array}{l}0.05 \\
(1.05)\end{array}$ & & $\begin{array}{l}0.07 \\
(0.55)\end{array}$ & \\
\hline Bankdummy*Q*Package & $\begin{array}{l}-0.01 * * \\
(-2.46)\end{array}$ & & $\begin{array}{l}-0.02 * * * \\
(-2.73)\end{array}$ & & $\begin{array}{l}0.08^{*} \\
(1.83)\end{array}$ & \\
\hline Bankshare & & $\begin{array}{l}0.18^{* *} \\
(2.36)\end{array}$ & & $\begin{array}{l}0.19 * * * \\
(2.87)\end{array}$ & & $\begin{array}{l}0.08^{* *} \\
(2.08)\end{array}$ \\
\hline Bankshare*Q & & $\begin{array}{l}-0.01^{*} \\
(-1.84)\end{array}$ & & $\begin{array}{l}-0.01 * * \\
(-2.49)\end{array}$ & & $\begin{array}{l}0.03 * * \\
(2.26)\end{array}$ \\
\hline Bankshare*Package & & $\begin{array}{l}0.02 \\
(1.40)\end{array}$ & & $\begin{array}{l}0.02 * \\
(1.72)\end{array}$ & & $\begin{array}{l}0.08 \\
(0.66)\end{array}$ \\
\hline Bankshare*Q*Package & & $\begin{array}{l}-0.02 * * \\
(-2.51)\end{array}$ & & $\begin{array}{l}-0.02 * * * \\
(-2.80)\end{array}$ & & $\begin{array}{l}0.05^{*} \\
(1.65)\end{array}$ \\
\hline Package & $0.09 * * *$ & $0.03 * * *$ & $0.09 * *$ & $0.03 * *$ & $0.07 *$ & $0.03 *$ \\
\hline
\end{tabular}




$\begin{array}{lllllll} & (3.30) & (2.57) & (2.47) & (2.49) & (1.76) & (1.83) \\ & 0.07^{* * *} & 0.06^{* *} & 0.09^{* * *} & 0.06^{* *} & 0.04^{* *} & 0.06^{* *} \\ & (2.98) & (2.11) & (3.07) & (2.32) & (2.25) & (2.11)\end{array}$

Other control variables include leverage, income, firm size, sales, tangibility, year and industry fixed effects

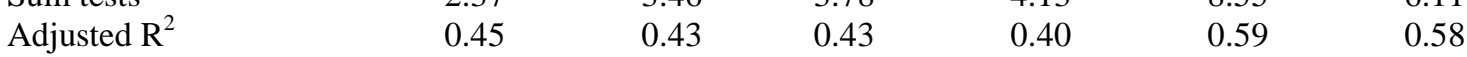

$\begin{array}{lllllll}\text { Observations } & 8476 & 8476 & 5939 & 5939 & 2537 & 2537\end{array}$

a Reports the significance tests of the sum of the estimated coefficients between ROS and Bankdummy*ROS*Package, and between ROS and Bankshare*ROS*Package in each regression.

${ }^{\mathrm{b}}$ Reports the significance tests of the sum of the estimated coefficients of $Q$ and Bank* ${ }^{*}$ Package in each regression.

This table reports the regression results using natural experiment method to address the endogeneity issue of bank ownership. Package is a dummy variable equal to 1 for firm-year observations falling during the post-ESP period. All the variables are defined the same as those in Table 6.

The T-statistics are in parentheses and were computed using the White (1980) heteroscedasticity robust standard error, clustered by firm, while *, **, *** indicate the significance levels at $10 \%, 5 \%$ and $1 \%$, respectively.

In addition, we also choose the two-stage least square (2SLS) approach to address this endogeneity issue. In the first stage we regress bank ownership against a set of control variables, and in the second stage we use the predicted value of bank ownership obtained from the first stage as a proxy for bank ownership in the investment equation. Moreover, we also apply the fixed effect regression to further check the robustness of our results. Following the discussion by Lang et al. (1996), Aivazian et al. (2005) and Firth et al. (2008), we use the firm fixed effect panel data regression to mitigate the unobservable time-invariant firm effect. Lang et al. (1996) assume that the unobservable individual effect is zero and use a pooling regression to estimate the investment equation, while Aviazian et al. (2005) argue there is large heterogeneity across industries and across firms within the same industry, so to control for individual firm heterogeneity they suggest that the fixed effect model would be more appropriate (Firth et al., 2008). To be robust and consider both scenarios, we also estimate the regression results with fixed effect regression and obtain similar results.

\subsection{Additional tests and discussion}

Our findings suggest that bank ownership affects both bank lending decisions and firm investment behaviour differently between SOEs and non-SOEs. Because this study proposes that banks' ex ante monitoring on their lending decisions affects firm investment policies, and it is the mechanism through which bank ownership affects firm performance, thus it is interesting to explore whether bank ownership influences firm performance in the same way as it influences lending and investment in our hypotheses. To test our additional hypothesis we conduct the following equation:

$$
\begin{aligned}
\text { Performance }_{i t} & =\alpha_{0}+\alpha_{1} \text { Bank }_{i t-1}+\alpha_{2} \text { Bank }_{i t-1} * \text { Investment }_{i t}+\alpha_{3} \text { Investment }_{i t} \\
& +\alpha_{4} \text { Size }_{i t}+\alpha_{5} \text { Leverage }_{i t}+\alpha_{6} \text { Largest }_{i t}+\alpha_{7} \text { Board }_{i t} \\
& +\alpha_{8} \text { Indep }_{i t}+\varepsilon_{i t}
\end{aligned}
$$


where Performance is the measure of firm performance. We apply return on assets (ROA) as a proxy for firm performance. All the other variables are defined the same as those in equation (1). The regression results are reported in Table 8 . As in our equation (2), we assume that firm investment is determined by a set of variables which are also included in equation (3), thus our regression suffers from an endogenous issue. To address this issue we apply the 2SLS method. In the first stage we estimate our equation (2) by adding the regional index as the instrumental variable following Fan et al. (2011), and dropping the interaction term between bank ownership and Tobin's Q. In the second stage the value of investment is the predicted value obtained from the first stage (our equation 2). We report the results for the first and second stage in Table 8.

As can be seen from Table 8 and Panel A, we find that the regional index is positively related to firm investment expenditures, indicating that the firm average investment level is significantly higher in the area with better development. In Panel B we find evidence supporting our hypothesis that bank ownership affects firm performance through investment policy differently between SOEs and non-SOEs. For the full sample we find that both bank ownership and the interaction term between bank ownership and investment are negatively related to firm performance which is consistent with the previous evidence in emerging markets (Fok et al., 2004; Lin et al., 2009). However, we are curious about the bank ownership effect on firm performance and rerun the regression for both SOEs and non-SOE sub-samples respectively, and report the results in columns 3 to 6 . In particular, we observe that bank ownership has a negative effect on firm performance for SOEs. When we combine the net effect of Bankdummy*PInvestment and PInvestment, we find that investment is negatively related to firm performance for SOEs. For example, in column 3 the estimated coefficients on Bankdummy*PInvestment and PInvestment are -0.33 and 0.15 significant at $5 \%$ and $1 \%$ levels ( $t$-values are -2.18 and 6.03$)$, and the net effect is negative $(-0.33+0.15=-$ 0.18), whereas the opposite effect occurs in the non-SOE sub-sample. For instance, in column 5 the estimated coefficients on Bankdummy*PInvestment and PInvestment are 0.09 and 0.23 significant at $5 \%$ and $1 \%$ levels (t-values are 2.55 and 3.56), and the net effect is positive $(0.09+0.23=0.32)$, indicating that investment is positively related to firm performance. Furthermore, a similar effect occurs when we apply the percentage of shares held by bank shareholders as the measure of bank ownership. In general, our results suggest that bank ownership has a negative effect on firm performance in SOEs and a positive effect on firm performance in non-SOEs. As a robustness check, we rerun our equation (2) by applying different proxies for firm performance, including return on sales (ROS) and Tobin's Q (Q), 
and we find results that are similar to those reported in Table 8. Overall, our study suggests that bank ownership helps SOEs obtain easier access to bank loans but does not exert enough monitoring over their loans or how they are used. However, in non-SOEs bank ownership is more likely to exercise monitoring functions which improves firm performance. We argue that whether bank ownership is positively related to firm performance relies on firm investment policy.

Table 8. Regression results of bank ownership on firm performance: 2SLS method

\begin{tabular}{|c|c|c|c|c|c|c|}
\hline & \multicolumn{2}{|l|}{ Full sample } & \multicolumn{2}{|l|}{ SOES } & \multicolumn{2}{|l|}{ Non-SOEs } \\
\hline \multicolumn{7}{|c|}{ Panel A: The results for the first stage where dependent variable is investment expenditures } \\
\hline Bankdummy & $\begin{array}{l}0.02 * * * \\
(3.44)\end{array}$ & & $\begin{array}{l}0.01 \\
(1.01)\end{array}$ & & $\begin{array}{l}0.03 * * * \\
(4.21)\end{array}$ & \\
\hline Bankshare & & $\begin{array}{l}0.16^{* *} \\
(2.20)\end{array}$ & & $\begin{array}{l}0.11 \\
(1.47)\end{array}$ & & $\begin{array}{l}0.29 * * * \\
(3.21)\end{array}$ \\
\hline Q & $\begin{array}{l}0.05^{* * *} \\
(4.53)\end{array}$ & $\begin{array}{l}0.05^{* * *} \\
(4.58)\end{array}$ & $\begin{array}{l}0.04 * * * \\
(3.07)\end{array}$ & $\begin{array}{l}0.05^{* * *} \\
(3.11)\end{array}$ & $\begin{array}{l}0.06^{* * *} \\
(3.11)\end{array}$ & $\begin{array}{l}0.04^{* * *} \\
(3.14)\end{array}$ \\
\hline Leverage & $\begin{array}{l}-0.20 * * * \\
(-4.35)\end{array}$ & $\begin{array}{l}-0.19 * * * \\
(-4.31)\end{array}$ & $\begin{array}{l}-0.06 \\
(-1.13)\end{array}$ & $\begin{array}{l}-0.06 \\
(-1.07)\end{array}$ & $\begin{array}{l}-0.40 * * * \\
(-5.72)\end{array}$ & $\begin{array}{l}-0.41^{* * *} \\
(-5.77)\end{array}$ \\
\hline Income & $\begin{array}{l}0.23 \\
(1.53)\end{array}$ & $\begin{array}{l}0.24 \\
(1.53)\end{array}$ & $\begin{array}{l}0.30 * * * \\
(4.83)\end{array}$ & $\begin{array}{l}0.30 * * * \\
(4.96)\end{array}$ & $\begin{array}{l}0.17 * * * \\
(2.66)\end{array}$ & $\begin{array}{l}0.18^{* * *} \\
(2.65)\end{array}$ \\
\hline Size & $\begin{array}{l}0.08 * * * \\
(8.69)\end{array}$ & $\begin{array}{l}0.08 * * * \\
(8.55)\end{array}$ & $\begin{array}{l}0.07 * * * \\
(6.55)\end{array}$ & $\begin{array}{l}0.07 * * * \\
(6.46)\end{array}$ & $\begin{array}{l}0.09 * * * \\
(5.47)\end{array}$ & $\begin{array}{l}0.09 * * * \\
(5.47)\end{array}$ \\
\hline Sales & $\begin{array}{l}-0.08 * * * \\
(-4.69)\end{array}$ & $\begin{array}{l}-0.08 * * * \\
(-4.67)\end{array}$ & $\begin{array}{l}-0.10^{* * *} \\
(-4.31)\end{array}$ & $\begin{array}{l}-0.10 * * * \\
(-4.30)\end{array}$ & $\begin{array}{l}-0.05^{* *} \\
(-2.14)\end{array}$ & $\begin{array}{l}-0.05^{* *} \\
(-2.08)\end{array}$ \\
\hline Tangibility & $\begin{array}{l}0.34^{* * *} \\
(5.84)\end{array}$ & $\begin{array}{l}0.34^{* * *} \\
(5.84)\end{array}$ & $\begin{array}{l}0.29 * * * \\
(4.23)\end{array}$ & $\begin{array}{l}0.29 * * * \\
(4.23)\end{array}$ & $\begin{array}{l}0.38^{* * *} \\
(3.73)\end{array}$ & $\begin{array}{l}0.38^{* * *} \\
(3.70)\end{array}$ \\
\hline Regional index & $\begin{array}{l}0.30 * * * \\
(4.62)\end{array}$ & $\begin{array}{l}0.29 * * * \\
(4.56)\end{array}$ & $\begin{array}{l}0.37 * * * \\
(3.69)\end{array}$ & $\begin{array}{l}0.37^{* * *} \\
(3.65)\end{array}$ & $\begin{array}{l}0.28 * * * \\
(3.94)\end{array}$ & $\begin{array}{l}0.27^{* * *} \\
(3.92)\end{array}$ \\
\hline Constant & $\begin{array}{l}-0.15^{* * *} \\
(-7.09)\end{array}$ & $\begin{array}{l}-0.14 * * * \\
(-6.98)\end{array}$ & $\begin{array}{l}-0.13 * * * \\
(-5.38)\end{array}$ & $\begin{array}{l}-0.11 * * * \\
(-5.31)\end{array}$ & $\begin{array}{l}-0.16^{* * *} \\
(-4.29)\end{array}$ & $\begin{array}{l}-0.16^{* * *} \\
(-4.30)\end{array}$ \\
\hline Year fixed effects & Included & Included & Included & Included & Included & Included \\
\hline Industry fixed effects & Included & Included & Included & Included & Included & Included \\
\hline Adjusted $\mathrm{R}^{2}$ & 0.56 & 0.55 & 0.63 & 0.63 & 0.62 & 0.59 \\
\hline Observations & 8476 & 8476 & 5939 & 5939 & 2537 & 2537 \\
\hline Panel B: The results for the & second stage & nere depen & t variable & rm perforn & nce & \\
\hline Bankdummy & $\begin{array}{l}-0.02 * * \\
(-2.23)\end{array}$ & & $\begin{array}{l}-0.05^{* *} \\
(-2.59)\end{array}$ & & $\begin{array}{l}0.02 * * * \\
(2.86)\end{array}$ & \\
\hline Bankdummy*PInvestment & $\begin{array}{l}-0.24 * * \\
(-2.24)\end{array}$ & & $\begin{array}{l}-0.33^{* *} \\
(-2.18)\end{array}$ & & $\begin{array}{l}0.09 * * \\
(2.55)\end{array}$ & \\
\hline Bankshare & & $\begin{array}{l}-0.23 * * * \\
(-2.76)\end{array}$ & & $\begin{array}{l}-0.25^{* * *} \\
(-3.00)\end{array}$ & & $\begin{array}{l}0.41^{* *} \\
(1.97)\end{array}$ \\
\hline Bankshare*PInvestment & & $\begin{array}{l}-0.27 * * * \\
(-2.70)\end{array}$ & & $\begin{array}{l}-0.37 * * \\
(-2.47)\end{array}$ & & $\begin{array}{l}0.03^{* *} \\
(2.11)\end{array}$ \\
\hline PInvestment & $\begin{array}{l}0.15^{* * *} \\
(6.35)\end{array}$ & $\begin{array}{l}0.16^{* * *} \\
(6.75)\end{array}$ & $\begin{array}{l}0.15^{* * *} \\
(6.03)\end{array}$ & $\begin{array}{l}0.15^{* * *} \\
(6.28)\end{array}$ & $\begin{array}{l}0.23 * * * \\
(3.56)\end{array}$ & $\begin{array}{l}0.25^{* * *} \\
(3.55)\end{array}$ \\
\hline Size & $\begin{array}{l}0.02 * * * \\
(14.003)\end{array}$ & $\begin{array}{l}0.02 * * * \\
(14.00)\end{array}$ & $\begin{array}{l}0.02 * * * \\
(11.88)\end{array}$ & $\begin{array}{l}0.02 * * * \\
(11.78)\end{array}$ & $\begin{array}{l}0.03 * * * \\
(7.47)\end{array}$ & $\begin{array}{l}0.03^{* * *} \\
(7.57)\end{array}$ \\
\hline Leverage & $\begin{array}{l}-0.19 * * * \\
(-13.08)\end{array}$ & $\begin{array}{l}-0.19 * * * \\
(-12.90)\end{array}$ & $\begin{array}{l}-0.17 * * * \\
(-13.07)\end{array}$ & $\begin{array}{l}-0.17 * * * \\
(-11.91)\end{array}$ & $\begin{array}{l}-0.20 * * * \\
(-5.95)\end{array}$ & $\begin{array}{l}-0.20 * * * \\
(-5.99)\end{array}$ \\
\hline Largest & $\begin{array}{l}0.02 * * * \\
(4.79)\end{array}$ & $\begin{array}{l}0.02^{* * *} \\
(4.72)\end{array}$ & $\begin{array}{l}0.02^{* * *} \\
(3.70)\end{array}$ & $\begin{array}{l}0.02^{* * *} \\
(3.68)\end{array}$ & $\begin{array}{l}0.02^{* *} \\
(2.24)\end{array}$ & $\begin{array}{l}0.02 * * \\
(2.28)\end{array}$ \\
\hline Board & $\begin{array}{l}0.03 \\
(0.72)\end{array}$ & $\begin{array}{l}0.03 \\
(0.75)\end{array}$ & $\begin{array}{l}0.06 \\
(1.34)\end{array}$ & $\begin{array}{l}0.06 \\
(1.35)\end{array}$ & $\begin{array}{l}0.03 \\
(0.39)\end{array}$ & $\begin{array}{l}0.03 \\
(0.42)\end{array}$ \\
\hline Indpe & $\begin{array}{l}0.05 \\
(0.79)\end{array}$ & $\begin{array}{l}0.05 \\
(0.79)\end{array}$ & $\begin{array}{l}0.06 \\
(0.72)\end{array}$ & $\begin{array}{l}0.06 \\
(0.74)\end{array}$ & $\begin{array}{l}0.04 \\
(0.36)\end{array}$ & $\begin{array}{l}0.04 \\
(0.37)\end{array}$ \\
\hline Constant & $-0.35^{* * *}$ & $-0.35 * * *$ & $-0.32 * * *$ & $-0.33 * * *$ & $-0.47 * * *$ & $-0.47 * * *$ \\
\hline
\end{tabular}




\begin{tabular}{lllllll}
\hline & $(-11.83)$ & $(-11.83)$ & $(-9.82)$ & $(-9.77)$ & $(-7.12)$ & $(-7.18)$ \\
Year fixed effects & Included & Included & Included & Included & Included & Included \\
Industry fixed effects & Included & Included & Included & Included & Included & Included \\
Sum tests $^{\text {a }}$ & $3.44^{* * *}$ & $4.62^{* * *}$ & $2.80^{* * *}$ & $4.78^{* * *}$ & $3.33^{* * *}$ & $3.66^{* * *}$ \\
Adjusted R $^{2}$ & 0.33 & 0.33 & 0.26 & 0.25 & 0.43 & 0.43 \\
Observations & 8476 & 8476 & 5939 & 5939 & 2537 & 2537 \\
\hline
\end{tabular}

${ }^{a}$ Reports the significance tests of the sum of the estimated coefficients between PInvestment and Bankdummy*PInvestment, and between PInvestment and Bankshare*PInvestment in each regression.

This table reports the results where we estimate firm performance against bank ownership and other control variables. Panel A reports the first stage results where dependent variable is firm investment. Regional index is the index composited by Fan et al. (2011) as the proxy for regional development. Panel B reports the second stage results where dependent variable is firm performance, measured as return on assets (ROA). PInvestment is the predicted value of firm investment obtained from the first stage. Largest is the percentage of shares held by the largest shareholder. Board is the log of number of director on the boards. Indep is the percentage of independent directors to total number of directors on the boards. All the other variables are defined the same in previous tables.

The T-statistics are in parentheses and were computed using the White (1980) heteroscedasticity robust standard error, clustered by firm, while *, **, *** indicate the significance levels at $10 \%, 5 \%$ and $1 \%$, respectively.

\section{Conclusion}

The objective of this paper is to examine the financial implications of bank ownership to bank lending and firm investment efficiencies. Motivated by the existing mixed evidence of how bank ownership affects firm performance, we dig deeper to investigate the mechanism through which bank ownership influences firm performance, to explain the existing mixed evidence. We specifically reveal that bank lending decisions relate to firm investment policy, which is a mechanism resulting in different effects that bank ownership has on firm performance. We use data from China's listed firms and find that the presence of direct bank ownership relates to easier access to bank loans and higher investment expenditures. However, bank ownership affects lending and investment efficiencies between SOEs and non-SOEs quite differently in that bank ownership weakens bank lending and firm investment efficiencies for SOEs, while enhancing lending and investment efficiencies for non-SOEs.

Our results also provide evidence to support our hypothesis that whether bank ownership can increase firm performance depends heavily on whether investment is efficient or not. Our findings complement extant evidence that bank ownership facilitates investment through easier access to bank loans, but banks choose to extend less effective monitoring over their loans to affiliated SOEs. In contract bank ownership in non-SOEs, the bank actively monitors and strengthens the firm's investment efficiency. We also provide evidence that the economic stimulus package had a negative impact on economic efficiency in SOEs, with our results showing that low bank lending and investment efficiencies in firms with bank ownership is exacerbated by government intervention. 
Overall, we argue that in an emerging market, the effect of bank ownership on firms' investment efficiency and performance will depend on firms' ownership structure. Banks are more likely to exert monitoring functions for non-SOEs through a mechanism where they take ownership and lend to a firm based on their commercial judgement, which lead to an efficient investment and adds value to the firm. Conversely, bank ownership reduces investment efficiency and destroys firm value for SOEs. We shed light on the importance of bank ownership on firm decisions and performance through lending decisions and investment policies. 


\section{References:}

Aggarwal, R. K., Samwick., A., 2006. Empire-builing and shirkers: Investment, firm performance and managerial incentives. Journal of Corporate Finance 12(3), 489-515.

Allen, F., Qian, J., Qian, M., 2005. Law, finance, and economic growth in China. Journal of Financial Economics 77, 57-116.

Aivazian, V., Ge, Y., Qiu, J., 2005. The impact of leverage on firm investment: Canadian evidence. Journal of Corporate Finance 11, 277-291.

Barth, J., Caprio, G., Levine, R., 2006. Rethinking Bank Regulation, Till Angels Govern. Cambridge University Press.

Berger, A., N., Hasan, I., Zhou, M., 2009. Bank ownership and efficiency in China: What will happen in the world's largest nation? Journal of Banking and Finance 33, 113-130.

Bharath, S.T., Dahiya, S., Saunders, A., Srinivasan, A., 2011. Lending relationships and loan contract terms. Review of Financial Studies 24(4), 1141-1203.

Boot, A. W. A., 2000. Relationship banking: What do we know? Journal of Financial Intermediation 9, 7-25.

Bris, A., Welch, I., Zhu, N., 2006. The cost of bankruptcy, Chapter 7 liquidation vs. Chapter 13 reorganization. Journal of Finance 56(2), 1253-1303.

Byrd, D. T., Mizruchi, M. S., 2005. Bankers on the board and the debt ratio of firms. Journal of Corporate Finance 11, 1129-173.

Cao, F., 2008. Monetary and Financial Management. Peking University Press. (Chinese)

Chen, G., Firth, M., Xu, L., 2009. Does the type of ownership control matter? Evidence from China’s listed companies. Journal of Banking and Finance 33, 171-181.

Chen. S, Sun, Z., Tang, S., Wu, D., 2011. Government intervention and investment efficiency: Evidence from China. Journal of Corporate Finance 17, 259-271.

Chen, Y., Liu, M., Su, L., 2013. Greasing the wheels of bank lending: Evidence from private firms in China. Journal of Banking and Finance. Forthcoming.

Core, J.E., Holthausen. R.W., Larcker, D.F., 1999. Corporate governance, chief executive officer compensation, and firm performance. Journal of Financial Economics 51(3), 371-406. Cull, R., Xu, L., 2000. Bureaucrats, state banks, and the efficiency of credit allocation: the experience of Chinese state-owned enterprises. Journal of Comparative Economics 28, 1-41. Cull, R., Xu, L., 2003. Who gets credit? The behaviour of bureaucrats and state banks in allocating credit to Chinese state-owned enterprises. Journal of Development Economics 71, 533-559. 
Cull, R., Xu, L., 2005. Institutions, ownership, and finance: the determinants of profit reinvestment among Chinese firms. Journal of Financial Economics 77(1), 117-146.

Datta, S., Datta, M. I., Patel, A., 1999. Bank monitoring and the pricing of corporate public debt. Journal of Financial Economics 51, 435-449.

Engelberg, J., Gao, P., Parsons, C. A., 2012. Friends with money. Journal of Financial Economics 103, 169-188.

Faccio, M., 2010. Differences between politically connected and nonconnected firms: A cross-country analysis. Financial Management 39(3), 905-928.

Fama, E., 1985. What's different about banks? Journal of Monetary Economics 15, 29-39.

Fama, E. F., French, K. R., 1998. Taxes, financing decisions, and firm value. Journal of Finance 53(3), 819-843.

Fan, G., Wang, X., Zhu, H., 2011. The marketizatioin index of China: The process of regional marketization report 2011. Beijing: Economic Science Press.

Firth, M., Lin, C., Wong, S. M. L., 2008. Leverage and investment under a state-owned bank lending environment: Evidence from China. Journal of Corporate Finance 14, 642-653.

Firth, M., Lin, C., Liu, P., Wong, S. M. L., 2009. Inside the black box: Bank credit allocation in China’s private sector. Journal of Banking and Finance 33, 1144-1155.

Firth, M., Malatesta, P. H., Xin, Q., Xu, L., 2012. Corporate investment, government control, and financing channels: Evidence from China's listed companies. Journal of Corporate Finance 18, 433-450.

Fok, R., Chang, Y.-C., Lee,W.-T., 2004. Bank relationships and their effects on firm performance around the Asian financial crisis. Financial Management, 89-112.

Gorton, G., Schmid, F., 2000. Universal banking and the performance of German firms. Journal of Financial Economics 58, 29-80.

Harvey, C. R., Lins, K. V., Roper, A. H., 2004. The effect of capital structure when expected agency costs are extreme. Journal of Financial Economics 74(1), 3-30.

Hutchinson, M., Gul, F. A., 2004. Investment opportunity set, corporate governance and firm performance. Journal of Corporate Finance 10, 595-614.

Jensen, M. C., Meckling. W. H., 1976. Theory of the firm: Managerial behaviour, agency costs, and ownership structure. Journal of Financial Economics 3, 305-360.

Kang, J.-K., Shivdasani, A., 1995. Firm performance, corporate governance and top executive turnovers in Japan. Journal of Financial Economics 38, 29-58.

Kang, J.-K., Shivdasani, A., Yamada, T., 2000. The effect of bank relations on investment decisions: an investigation of Japanese takeover bids. Journal of Finance, 2197-2218. 
Kroszner, R.S., Strahan, P.E., 2001. Bankers on boards: monitoring, conflicts of interest, and lender liability. Journal of Financial Economics 62, 415-452.

Lang, L., Ofek, E., Stulz, R., 1996. Leverage, investment and firm growth. Journal of Financial Economics 40, 3-29.

Li, H. B., Meng, L., Wang, Q., Zhou, L., 2008. Political connections, financing and firm performance: Evidence from Chinese private firms. Journal of Development Economics 87, 283-299.

Limpahayom, P., Polwitoon, S., 2004. Bank relationship and firm performance: evidence from Thailand before the Asian financial crisis. Journal of Business Finance \& Accounting 31-9, 306-368.

Lin, X., Zhang, Y., Zhu, N., 2009. Does bank ownership increase firm value? Evidence from China. Journal of International Money and Finance 28, 720-737.

Luo, W., Zhang, Y., Zhu, N., 2011. Bank ownership and executive perquisites: New evidence from an emerging market. Journal of Corporate Finance 17, 352-370.

Mahrt-Smith, J., 2006. Should banks own equity stakes in their borrowers? A contractual solution to hold-up problems. Journal of Banking and Finance 30, 2911-2929.

Myers, S. C., 1977. The determinants of corporate borrowing. Journal of Financial Economics 5, 147-175.

Pindado, J., Requejo, I., Torre, C., 2011. Family control and investment-cash flow sensitivity: Empirical evidence from the Euro zone. Journal of Corporate Finance 17, 1389-1409.

Santos, J., Rumble, A.S., 2006. The American Keiretsu and universal banks: investing, voting and sitting on non-financials’ corporate boards. Journal of Financial Economics 80, 419-454. Stulz, R. M., 1990. Managerial discretion and optimal financing policies. Journal of Financial Economics 26, 3-27.

White, H., 1980. A heteroskedasticity-consistent covariance matrix estimator and a direct test for heteroskedasticity. Econometrica 48(4), 817-838.

Zheng, Y., Zhu, Y., 2013. Bank lending incentives and firm investment decisions in China. Journal of Multinational Financial Management 23, 146-165. 